\section{E-LOGOS}

ELECTRONIC JOURNAL FOR PHILOSOPHY ISSN 1211-0442

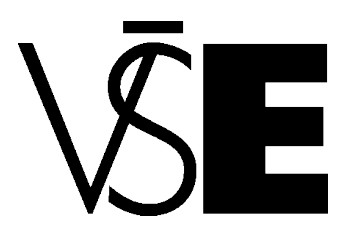

University of Economics

Prague

\title{
Kognitivní pohled na umělou inteligenci
}

Ondřej Vadinský

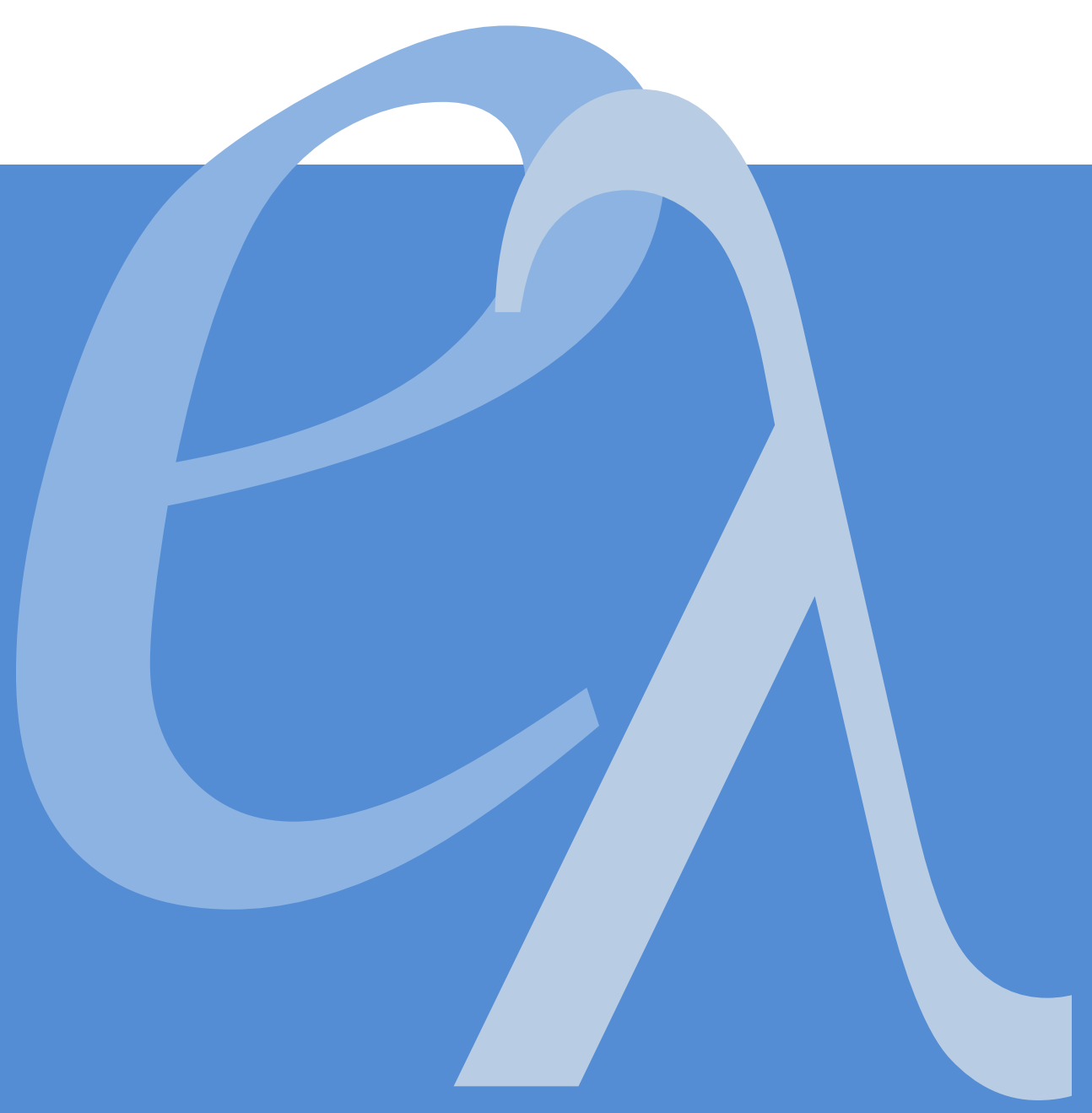




\section{Abstract}

My essay is inspired by reading of MARC DE MEY's Cognitive paradigm. I characterize his position as, what I call, a cognitive view. Further I characterize SEARLE'S concept of strong artificial intelligence. It is the creation of strong AI, that I consider to be the main goal for the field of artificial intelligence to strive for. I try to find out in which ways could a cognitive view be applied in our endeavour to create strong AI. These ways consist primarily of modelling of world representations, of plurality of such models capable of joining into some kind of unity, and of such a combination of stratified model of perception with actions that would create implicit and later also explicit knowledge.

\section{Abstrakt}

Tato má esej vychází z četby knihy MARCA DE MEYE Kognitioní paradigma. Na základě jeho výkladu kognitivního paradigmatu charakterizuji kognitivní pohled, který DE MEY zastává. Dále stručně charakterizuji SEARLOVO pojetí silné umělé inteligence, které vidím jako hlavní cíl, o jehož dosažení by disciplína umělé inteligence měla usilovat. Konečně pak zkoumám, jakým způsobem by se dala vytyčená kognitivní pozice uplatnit při snaze o vytvoření silné umělé inteligence. Průniky, které zde vidím, spočívají především v samotném modelování reprezentací světa, v mnohosti takových modelů schopných spojit se do jednotného celku a v propojení stratifikovaného modelu vnímání s akcemi, jež vede k vytvoření nejprve implicitní a posléze i explicitní podoby znalostí.

\section{Key words}

cognitive paradigm, plurality of world views, stratified model of perception, strong artificial intelligence, intentionality, logical symbolism, connectionism, hybrid systems

\section{Klíčová slova}

kognitivní paradigma, mnohost modelů světa, stratifikovaný model vnímání, silná umělá inteligence, intencionalita, logický symbolizmus, konekcionizmus, hybridní systémy 


\section{1 Úvod}

Při úvahách o vytvoření umělé inteligence narážíme na nutnost poznání samotné inteligence. V tomto ohledu se našemu poznání jako nejpřístupnější jeví inteligence lidská, ač s nutností odhlédnout od samozřejmosti, se kterou k ní jako lidé přistupujeme. Vědeckou reflexi inteligence v kontextu lidského myšlení, vnímání, paměti, řeči, vědomí a dalších aspektů bytí člověkem poskytuje transdisciplinární kognitivní věda. Ke shrnutí kognitioního paradigmatu poslouží stejnojmenná kniha MARCA DE MEYE.

Kromě reflektování lidské inteligence je však třeba uvažovat i nad konceptem umělé inteligence. Zde vedle stručné charakteristiky paradigmat, jež disciplínu umělé inteligence určují, předkládám shrnutí filozofické reflexe SEARLOVY. Ta mimo jiné hovoří o silném a slabém pojetí umělé inteligence. Právě vytvoření silné umělé inteligence - umělé inteligence srovnatelné s tou lidskou - vidím jako primární cíl snah disciplíny umělé inteligence.

Po vymezení kognitivního paradigmatu a silné umělé inteligence lze hledat odpovědi na otázku: Jakým způsobem může uplatnění kognitivního pohledu na problematiku inteligence přispět ke snaze o vytvoření silné umělé inteligence?

\section{Kognitivní pohled}

Ústřední myšlenkou kognitivizmu je to, že zpracování informací nějakým systémem vyžaduje, aby tento systém měl nějakou formu interního modelu či reprezentace prostředí, v němž se vyskytuje. Viz [1, str. xxvii]. I pro porozumění těm nejjednodušším výrokům je potřeba komplexní model - DE MEYEM označovaný jako náhled na svět ${ }^{1}$ obsahující spoustu z hlediska rozumění nutných znalostí. Viz [1, str. 16]. Jak DE MEY dále ukazuje, nejde o model jediný, ale o relativně volné, proměnné seskupení mnoha různě precizně vypracovaných a svou strukturou odlišných náhledio na svět. Viz [1], str. 20 -22]. Mnohost náhledů na svět spolu s mechanizmem umožňujícím jejich různé kombinace a přepínání role hlavního náhledu na svět a konečně i s mechanizmem umožňujícím z jednoho náhledu generovat další možné náhledy tvoří dynamická kognitioní schémata - strukturu spojující a organizující znalosti o konceptech. Toto pojetí považuje DE MEY za nutné pro samu životaschopnost kognitivizmu. Viz [1, str. 225].

Významným způsobem zpracování informací je vnímání. Toto vnímání je bez ohledu na předmět vždy nepřimé, nebot' je zprostředkované některým z náhledů na svět. Viz [1, str. 26]. DE MEY uvádí tzv. stratifikovaný model vnímání. Při takovém chápání není vnímání pouhým skládáním z dílčích vjemů. Ke vnímanému objektu přistupuje subjekt po vrstvách, jež jsou na sobě částečně nezávislé a $\mathrm{k}$ nimž lze i částečně nezávisle přistupovat. Vnimaný objekt je tak amalgámem vnořených tvarů na různých stupních rozlišení zpevněným vztahy část-celek v síti pojmů dodané náhledem na svět. Jak objekt, tak i subjekt přispívají ke vnímání. Vnímané tvary jsou tedy jak zaregistrované, tak i před-

\footnotetext{
${ }^{1} \mathrm{~V}$ originále „world view“.
} 
stavované a na základě sítě pojmů nesoucí očekávání. Celek se tak stává částí vedle částí samých. Viz [1, str. 182-191]. Při vnímání dochází k interaktivní konstrukci objektu i jeho pozadí na základě kontextu dodaného náhledem na svět. Přitom dochází k výběru různých invariantů $\mathrm{v}$ různých rozsazích, jenž jsou při interpretaci konstruující objekt i pozadí kombinovány. Viz [1, str. 253-255].

Na první pohled zřejmé distinkce já - svět či vnitřní-vnější se při bližším pohledu začínají jevit jako ambivalentní. Takovéto distinkce se podle DE MEYE nacházejí v každém náhledu na svět a nejsou tedy nějak o sobě dány. Viz [1, str. 26]. Zásadním problémem porozumění poznání pak je to, jak si část světa vyvine model celku, ve kterém se reprezentuje jako od celku se lišící. Viz [1, str. 27]. Protože samotný koncept náhledu na svět predchází distinkci já-svět, existují v různých náhledech na svět různé distinkce jásvět. Ty pak mohou být navzájem nekompatibilní a tím ztěžovat skládání jednotlivých náhledů na svět. Viz [1, str. 219]. S mnohostí náhledů na svět je tak spojena mnohost já. Viz [1, str. 248]. Kontext je všudypřítomným pojmem, který se podílí i na rozboření hranic mezi já a svět i vnitřní a vnější. Viz [1, str. 253].

Kontext poskytuje subjektu znalost vyšší úrovně, díky které dokáže vybrat z hlediska této znalosti interpretačně relevantní části zprávy. Viz [1, str. 14-16]. Znalosti obsažené $\mathrm{v}$ náhledech na svět jsou primárně tacitní součástí praktických schopností a vzorů pozornosti. Viz [1, str. 20]. S DE MEYOVÝM uchopením znalostí kromě KUHNOVSKÝCH paradigmat také úzce souvisí MINSKÉHO rámce a PIAGETOVA vývojová psychologie. Viz [1, str. 106]. Pro pochopení lidské převahy se jako zásadní jeví především způsob organizace znalostí, jejich propletenost s akcí a paradigmaty. Viz [1, str. 202-203]. MINSKÉHO rámce jsou komplexní struktury představující kostru, do které lze zapasovat konkrétní znalosti. Tato kostra rámce je poměrně pevná a je vždy celkem volně spjatá s výchozími hodnotami, tedy s očekáváním doplnitelných znalostí. Rámce lze různým způsobem spojovat do složitých systémů, jejichž vazby jsou však relativně slabé, a tedy umožňují zásadní přestavbu. Rámce jsou napasovány na znalosti, i když dochází k rozporu výchozích hodnot a nových znalostí. Tento rozpor je však uznán a podílí se na dalším zpřesňování struktury rámců, je-li takového zpřesnění zapotřebí. Dokud to však lze, nakládá se s různým jako se stejným. Neznámé tak zůstává pod kontrolou známého a proniká a mění ho pouze pozvolně. Propojení rámců s cíli je pak obdařuje účelem. Cíle i rámce jsou uspořádány heterarchicky, vytváří tak pouze dočasné a z dlouhého pohledu tedy proměnné hierarchie. Podle kontextu se tak důležitost prvků systému překlápí. Znalosti jsou pevně spjaté se svým použitím, a tedy i se subjektem. Nejsou tak pouze o „vnějšku“ ale i o „vnitřku“. Cvikem dochází ke zpřesňování stereotypického a dosahování mistrovství. Viz [1, str. 204-216]. PIAGET dále popisuje vztah akce a znalostí, jenž prochází několika stádii, kde je podstatnou částí uvědomění si interakce subjektu a objektu. Vytvoření konceptuálního systému pak umožňuje plánování akce, ale také abstrakci od konkrétního a přechod k formálnímu. Tato schopnost potvrzená existencí principu zachování pak značí uzavření konceptuálního systému, jeho koherenci a autonomii. Viz [1, str. 227-245]. Znalosti se netýkají pouze „vnějšku“; jde o udržování rovnováhy mezi poznávaným objektem a pozná- 
vajícim subjektem. Jak ukazuje PIAGET, poznávání světa je spjaté s poznáváním sebe samého. Sebeznalost je tak více rozrůzněnou reprezentací možných akcí subjektu vykonatelných na rozrůzněné reprezentaci objektu. Subjekty jsou tak ustavovány spolu s vnějším světem, který poznáváme a tvoříme. ${ }^{2}$ Viz [1, str. 258-259].

Zejména v souvislosti s paradigmaty je kognitivní pozice značně relativistická. Různá paradigmata mají stejnou schopnost poskytnout kognitioní mapu světa. Náhledy na svět vyžadují určení možných rolí a akcí subjektu, stejně jako i možných stavů objektu. V tomto pojetí lze o paradigmatech hovořit jako o poskytujících perspektivu pro vnímání a poznávání světa. Viz [1, str. 224]. Relativizmus hraje klíčovou roli i v PIAGETOVĚ vývojové teorii. Vrcholné stadium vývoje znamená právě dosažení vyspělého relativizmu spjatého s rozrůzněním subjekt-objekt a schopnost relativizovat různé náhledy na svět či vztáhnout se k jinému náhledu. Viz [1, str. 230]. A konečně sama mnohost náhledů na svět zdůrazňovaná MIT školou umělé inteligence je potvrzením tohoto relativizmu. $\mathrm{K}$ tomu však DE MEY říká, že představa relativizmu pojícího se pouze s přístupem "cokoliv je možné“ je značně nepřesná. Podle něj lze být relativistou a držet se přísných pravidel přípustnosti. Viz [1, str. 256].

Výše uvedený kognitivní pohled nyní stručně shrnu tím, že zdůrazním tyto jeho aspekty:

- existence mnoha modelů světa a schopnost je dynamicky kombinovat;

- stratifikovaný model vnímání, k němuž přispívají jak vstupy objektu (vjemy), tak očekávání subjektu (generovaná modelem);

- redefinice mnoha distinkcí (včetně já - svět) jako sekundárních, tedy jsoucích součástí konkrétních modelů (a z toho plynoucí mnohost já);

- propojenost znalostí s akcemi, specifický způsob jejich uložení a vývoje, důraz na sebeznalost;

- relativizmus spojený s přísnými požadavky na přípustnost.

\section{Silná umělá inteligence}

Pozici silné a slabé umělé inteligence SEARLE diskutuje v souvislosti se svým známým argumentem čínského pokoje ${ }^{3}$. Hlavní rolí počítače v oboru slabé umělé inteligence je být

\footnotetext{
${ }^{2}$ V originále: „,Selves' are made along with the external world we investigate and create.“ [1, str. 259].

${ }^{3} \mathrm{~V}$ myšlenkovém experimentu známém jako čínský pokoj se Searle snaží vžít do role počítače. Uzavírá se tedy jako rodilý anglický mluvčí do pokoje, kam mu přicházejí zprávy v čínských znacích. S využitím knihy, která mu anglicky říká, jak má čínské znaky přeskupit, odpovídá v čínštině na původní zprávu tak, že si rodilí Č́ínané venku myslí, že muž v pokoji umí čínsky. Searle však tvrdí, že rozumí pouze anglickým instrukcím v knize, tedy programu, který vykonává, nikoliv však čínským znakům, s nimiž pouze manipuluje podle formálních pravidel. $Z$ toho Searle vyvozuje, že rozumění, ač může být zvenčí připisováno, nemusí se nutně uvnitř uskutečňovat. To, co rozumění umožňuje, je intencionalita, jež je způsobena kauzálními schopnostmi specifické biologické struktury lidského mozku. Viz [2].
} 
mocným nástrojem při zkoumání lidské mysli. Oproti tomu SEARLOVO pojetí silné umělé inteligence chápe jako hlavní úlohu počítače být oysvětlením lidské mysli. Naprogramovaný počítač tak má mít kognitivní stavy a má být duplikací lidské mysli, tedy myslí sám o sobě. V tomto pojetí pak počítač (resp. jeho program) rozumí tomu, co zpracovává. $\mathrm{Viz}$ [2].

Dále se SEARLE věnuje vymezení toho, co je lidské inteligenci vlastní a co by tedy počítače v rámci silné umělé inteligence měly duplikovat. Tím je podle SEARLA intencionalita, kterou definuje jako vlastnost určitých mentálních stavů, jež je činí zaměřenými na objekty a situace ve světě, nebo jsoucími o těchto objektech a situacích. Intencionalita tak souvisí s bytím o něčem a s porozuměním pojmu, jež se skrývá za symbolem. ${ }^{4}$ $\mathrm{V}$ případě lidské mysli je intencionalita způsobena kauzálními schopnostmi lidského mozku a jeho specifickou biochemickou strukturou. Zde je mozek chápán jako specifický druh stroje, a tedy stroje mohou myslet, mají-li určité vlastnosti, díky kterým mají intencionalitu. SEARLE však také upozorňuje na jinou vlastnost lidské mysli: Ta ráda připisuje intencionalitu (schopnost rozumění) jen na základě pouhé podobnosti s naším chováním, čímž se podle SEARLA dopouští mnoha omylů jak v případě zvířat, tak i v případě počítačů. Proto je při zjišt'ování, zda je systém inteligentní, rozhodující původ intencionality. Pokud ta pochází ze systému samotného, tak jde o inteligentní systém. Avšak pochází-li intencionalita z jiného systému, je to ve skutečnosti inteligence onoho jiného systému, kterou tento do daného systému vkládá. Viz [2].

\section{Uplatnění kognitivního pohledu při konstrukci silné umělé inteligence}

Kognitivní věda je interdisciplinárním vědním oborem studujícím lidskou mysl, který mimo jiné čerpá z oboru umělé inteligence a filozofie. Uplatňování kognitivního pohledu na umělou inteligenci by se tak mohlo zdát poněkud podivné, vždyt' umělá inteligence je součástí kognitivní vědy. Interakce umělé inteligence a kognitivní vědy by se však neměla omezovat pouze na úroveň vstupu, ale měla by také probíhat na úrovni zpětné vazby. Poznatky kognitivní vědy by tak mohly sloužit jako stavební kameny pro tvorbu uměle inteligentních systémů, které budou srovnatelné s člověkem. V tomto pojetí definuje kognitivní věda předpoklady, jež musí inteligentní systém splňovat, aby o něm šlo hovořit jako o vskutku inteligentním.

Umělá inteligence nabízí tři paradigmata, jejichž metodami lze vytvářet náhledy na svět. Logický symbolizmus poskytuje metody explicitní reprezentace znalostí a je schopen dobře modelovat strukturu vyjádřených pojmů v lidské mysli. Jeho metody však mají problémy v situacích, kdy informace jsou neurčité, nejisté, či dokonce pro-

\footnotetext{
${ }^{4}$ V této souvislosti je vhodné zmínit PSTRUŽINOvo chápání intencionality, ve kterém figuruje jak zaměřenost na jsoucno pro sebe, tak ovšem i zvýznamnění intencionálního pojmu vřazením do komplexní struktury pojmů a endoceptů a konečně i reflexe tohoto zvýznamnění. Viz [3].
} 
tichůdné. Konekcionizmus oproti tomu prosazuje ideu jednoduchých výpočetních jednotek propojených do složité sítě, kde emergují vlastnosti, jež samy jednoduché jednotky nemají. Takové modely jsou pak implicitní a dokáží se vyrovnat s neurčitými, nejistými i protichůdnými informacemi. ${ }^{5}$ Hybridní systémy pak kombinují oba tyto př́ístupy, což vede k synergickému uplatnění implicitní a explicitní reprezentace znalostí, které jsou oboje obsaženy v mysli. Hybridní systémy nacházejí uplatnění v kognitioních architekturách, které se snaží modelovat lidskou kognici co nejrealističtějším způsobem. Viz [4, 5].

Jak vyplývá z popisu kognitivního pohledu, je tento značně spjatý s náhledy na svět, tedy s modely. Skrze ně se provádí veškeré zpracování informací, z nich vyplývají očekávání uplatňovaná při vnímání a jsou v nich jsou uloženy i znalosti. V rámci modelů jsou pak definovány distinkce mezi jednotlivými já a jednotlivými světy. Abychom tyto poznatky dokázali uplatnit v umělé inteligenci, musíme umět modelovat. Nejde však ani tak o naši lidskou schopnost modelovat, ale o automatické modelování, které bude probíhat v počítači bez nutnosti lidského zásahu. Tato automatičnost by pak neměla být pouze na úrovni naplňování předem stanoveného modelu, ale i na úrovni tvorby nových modelů. Zdá se totiž, že je schopností člověka vymýšlet různé modely svých znalostí. Samotných metod modelování nabízejí paradigmata umělé inteligence mnoho. Existují i metody různou měrou automatického naplňování těchto modelů. Metody vytváření nových druhů modelů mi však známy nejsou. Zde je tedy prostor pro další průzkum a také pro důkladné prověření výchozí hypotézy, že sice lidé dokáží tvořit různé (libovolné) modely, které se jen volně spojují a vytvářejí zdání jednotnosti. Nabízí se totiž protichůdné vysvětlení, podle kterého je člověk řízen jedním obecným modelem, ze kterého pouze odvozuje jiné reprezentace svých znalostí, čímž vzniká dojem plurality modelů. ${ }^{6}$ Potom by se tento bod u umělých systémů redukoval na nalezení modelu, jímž je člověk řízen, a mechanizmu odvozování nižších modelů a následnou implementaci všeho do počítače.

S DE MEYOVOU pozicí je silně spjatá představa mysli skládající se z mnoha dílčích jednotek, jež umí řešit značně specializované problémy a jejichž výstupy jsou pak zpracovávány dalšími jednotkami bez toho, aby tyto zasahovaly do samotného zpracovávání problémů. $S$ takovými jednotkami jsou pak spojeny jednotlivé náhledy na svět, které se při zpracování informací určitým způsobem kombinují. Opačná pozice

\footnotetext{
${ }^{5}$ Hranice mezi logickým symbolizmem a konekcionizmem není tak ostrá, jak by se z výše uvedeného shrnutí mohlo zdát. Historický vývoj a vzájemné ovlivňování, jimiž tato paradigmata prošla, vedly ke snaze odstranit jejich nedostatky úpravou používaných metod. Například implementací mechanizmů fuzzy logiky lze u logicko symbolického systému dosáhnout schopnosti vyrovnat se s neurčitostí informace. Obdobně existují způsoby, jakými v neuronových sítích pracovat se symbolickou reprezentací. Obě tato paradigmata navíc vycházejí z komputačního vysvětlení mysli a obě poskytují nějakou formu reprezentace světa.

${ }^{6}$ Kognitivní pojetí mysli si všímá dvou aspektů: mysl tvoří jakousi jednotu, zároveň však vykazuje prvky plurality. DE MEYEM prezentované vysvětlení staví do primární pozice ony části, jejichž kombinací vzniká druhotná jednota. Tyto aspekty však lze vysvětlit i tak, že mysl je primárně jednotná a až druhotně pluralitní tím, jak vystupuje v jednotlivých situacích.
} 
zastává jednotný pohled na mysl a jí odpovídající jednotný náhled na svět. Jak DE MEY ukazuje, dílčí pohledy na svět se mohou sdružovat a vytvářet paradigmata. Vzniká tak jednotná struktura, ačkoliv sjednocující vazby nejsou natolik pevné, aby vylučovaly pozdější přeskupení, či tak silné jako vazby uvnitř náhledů na svět. Obě tyto pozice se tak ukazují jako v určitých aspektech pravdivé a především i spojitelné do fungujícího celku. Mysl je tak unitární i pluralitní zároveň - objevuje se zde tedy HEGELOVSKÉ překonání-zachování. Obdobný moment lze nalézt i u DE MEYEM zmiňované heterarchie cílů, které se dokáží sdružit do dočasné, a tedy i proměnné hierarchie. Takto propracovaná pozice je lákavá z toho důvodu, že nalézáme poznatky podporující to i ono pojetí.

Vnímání je v kognitivní pozici chápáno jako složitý proces, jenž vyžaduje vysvětlení. Tímto vysvětlením je chápání vnímání zdůrazňující roli náhledu světa. Některé vjemy jsou rozeznány jako známé, na základě čehož jsou určeny koncepty náhledu světa, které jim jsou přiřazeny. Na základě souvisejících konceptů se pak mezi dalšími vjemy hledají tvary jim odpovídající, čímž do vnímání proniká predikce na základě známého. Důležitost, která se zde vnímání přisuzuje si žádá, aby i myslící stroje měly nějaké formy vnímání. Nakolik podobné smysly těm lidským by počítače měly mít, aby dokázaly myslet, je otázkou. Bereme-li člověka jako vzor inteligentní bytosti, vyplývá z toho i nutnost mít člověku podobné smysly. Na druhou stranu jsou tu technické možnosti překračující v některých aspektech i značnou měrou mocnosti lidských smyslů. ${ }^{7}$ Bylo by tedy zajisté na škodu možnosti vnímání strojů v tomto smyslu limitovat. Za úvahu však stojí i to, nakolik by takováto jinakost co do schopnosti vnímat omezovala možnosti interakce a vzájemného porozumění inteligentních strojů a lidí. Mluvíme-li o strojích a vnímání, je také na místě v souladu s kognitivní pozicí zdůrazňující akci uvažovat jako takovéto stroje roboty - autonomní stroje schopné vnímání skrze senzory a akce skrze aktuátory. Představa inteligentních strojů jako robotů se kromě vnímání světa opírá právě i o možnost akce ve světě a podle některých proponentů tohoto př́istupu tak umožní vznik intencionality v takovýchto robotech. I zde by mělo smysl vést úvahy o tom, jakou povahu by měly mít robotické akce ve světě. Cesta člověku podobných akcí, ač svým způsobem limitující, by měla přispět k možnostem vzájemné interakce a porozumění. Cesta využívající všech dostupných technických prostředků, stejně jako u vnímání, umožní překonat lidem daná omezení.

Velice zajímavou myšlenkou v DE MEYOVĚ knize je rozbourání hranic zažitých distinkcí jako vnitřní - vnější, ale zejména já - svět. Tyto běžně samozřejmé distinkce jsou podřazeny konkrétnímu náhledu na svět a tím jsou sesazeny ze svého prioritního postavení a také jsou značně relativizovány. Ve spojení s mnohostí náhledů na svět pak vyvstává zajímavá situace. Pojmy běžně chápané jako singulární se zmnožují. Na místo jednoho já se tak objevuje mnohost odlišných já specifických pro každý jeden náhled na svět. Odlišnost jednotlivých já jde navíc někdy až tak daleko, že jsou tato já spolu

\footnotetext{
${ }^{7}$ Zmiňme například omezení rozsahů vlnových délek lidmi vnímaného světla či frekvencí lidmi slyšitelného zvuku.
} 
nekompatibilní, čímž brání kombinaci náhledů na svět, jichž jsou součástí. Podobný koncept není zcela nový, lze jej přirovnat ke konceptu rolí, ve kterých lidé vystupují. Přesto ono nadřazení náhledu na svět distinkci já - svět by mohlo přinést zajímavé důsledky, což si zaslouží bližší průzkum. Je-li náhled na svět (model světa) primární a až po jeho vzniku následuje rozpad a vymezení já - svět, je otázkou, nakolik je takové pojetí sto převrátit zažité chápání mnoha běžně zastávaných pozic, jež naopak vycházejí z chápání distinkce já - svět jako primární. Vyvstává také otázka, co je to vlastně onen náhled na svět, když si zasluhuje tak významné postavení.

Relativizmus spjatý s kognitivní pozicí je značný. To umožňuje vysvětlit mnohé subjektivní rozdíly ve vnímání, chápání významu i poznání. Zároveň je však relativizmus, jak říká i sám DE MEY, silně spjat s představou všepřípustnosti. DE MEY sice říká, že lze zastávat relativizmus a dodržovat přitom přísná pravidla přípustnosti, ovšem to, jak by taková pravidla mohla vypadat či jaká kritéria by měla splňovat, nijak nerozvádí. Otázka relativizmu tak není zcela uspokojivě vyřešena.

\section{Závěr}

V této své eseji jsem se snažil o charakteristiku DE MEYOVA kognitivního pohledu. Tomu je vlastní především zdůraznění mnohosti náhledů na svět (modelů světa) prostřednictvím nichž se děje veškeré vnímání. Vnímání světa je tak společným dílem objektu a subjektu, ke kterému oba přispívají. V těchto modelech se také nachází distinkce já - svět, která se může mezi modely lišit a komplikovat tak jejich kombinaci. Pro kognitivní pozici je podstatná jak vnitřní organizace modelů světa, kde se jako vhodná představa jeví MINSKÉHO rámce, tak i způsob, jakým se náhledy na svět vyvíjejí, což dobře ukazuje PiAgetova vývojová psychologie. Kognitivní pozice je pevně spjata s relativizmem, jenž by měl být omezen př́ísnými pravidly přípustnosti. Těch správných sice může být $\mathrm{v}$ relativistickém pojetí nekonečně mnoho, nejsou to však všechna možná pravidla, tedy ani přístup, který připouští, že vše je možné.

Dále jsem shrnul SEARLŮV přístup k umělé inteligenci, jenž ji dělí na silnou a slabou podle toho, zda si klade za cíl duplikovat lidskou mysl, či jen vytvářet šikovné nástroje pro řešení složitých problémů. Jako primární cíl disciplíny umělé inteligence vidím právě snahu o vytvoření silné umělé inteligence, která by byla rovna té lidské.

V poslední části této eseje jsem se zaměřil na to, jak by šel kognitivní pohled využít při budování uměle inteligentního stroje. Snahu využít k tomu kognitivní znalosti považuji za důležitou především proto, že kognitivní věda zkoumá lidskou mysl, která je v tomto úkolu naším vzorem. Uplatnění výsledků kognitivní vědy je pak zpětnou vazbou pro oblast umělé inteligence. $V$ této oblasti jsem se dotkl několika důležitých aspektů, které by umělá inteligence měla při vývoji uměle inteligentního stroje využít. Prvním z nich je samotné modelování a především snaha o autonomnost takového procesu. Dalším je představa pluralitního uspořádání mysli se svou dynamikou umož- 
ňující kombinace do jednotných celků. S modelováním světa souvisí vnímání a možnost akce, tedy robotika. V ní se pak nabízí možnost překonání lidských omezení co do mocnosti smyslů i aktuátorů a zároveň vyvstává otázka, nakolik toto ovlivní samotné umělé myšlení a možnosti interakce a porozumění mezi lidmi a uměle inteligentními stroji. Zajímavým momentem v kognitivní pozici, který se mi nedaří zcela uchopit, je přesunutí distinkce já - svět do modelů, relativizace role já i světa a vyvstání mnohosti já a světů. Otevřenou otázkou pak také zůstávají principy př́ípustnosti, jež by měly zabránit kognitivnímu relativizmu, aby se zvrhl v pozici „cokoliv lze“. 


\section{Reference}

[1] Mey, M. DE: Cognitive Paradigm. Repr. Chicago and London: University of Chicago, 1992. 314 s. ISBN-10: 0-226-14259-0.

[2] SeARle, J. R.: Minds, Brains, and Programs. The Behavioral and Brain Sciences 3 (1980) 417-457.

[3] PstružInA, K.: Turing v Searleově čínské místnosti. Acta oeconomica Pragensia: vědecký časopis Vysoké školy ekonomické v Praze 11-8. (2003) 9-16.

[4] SUN, R.: Artificial intelligence: Connectionist and symbolic approaches. In: International Encyclopedia of the Social and Behavioral Sciences (N. J. Smelser, P. B. Baltes, eds.), Pergamon/Elsevier, Oxford. 2001: 783-789.

[5] SUN, R.: The Importance of Cognitive Architectures: An Analysis Based on CLARION. Journal of Experimental and Theoretical Artificial Intelligence 19-2 (2007) 159193. 


\section{E-LOGOS}

\section{ELECTRONIC JOURNAL FOR PHILOSOPHY}

Ročník/Year: 2012 (vychází průběžně/ published continuously)

Místo vydání/Place of edition: Praha

ISSN 1211-0442

Vydává/Publisher:

Vysoká škola ekonomická v Praze / University of Economics, Prague

nám. W. Churchilla 4

Czech Republic

13067 Praha 3

IČ: 61384399

Web: http://e-logos.vse.cz

Redakce a technické informace/Editorial staff and technical information:

Miroslav Vacura

vacuram@vse.cz

Redakční rada/Board of editors:

Ladislav Benyovszky (FHS UK Praha, Czech Republic)

Ivan Blecha (FF UP Olomouc, Czech Republic)

Martin Hemelík (VŠP Jihlava, Czech Republic)

Angelo Marocco (Pontifical Athenaeum Regina Apostolorum, Rome, Italy)

Jozef Kelemen (FPF SU Opava, Czech Republic)

Daniel Kroupa (ZU Plzeň, Czech Republic)

Vladimír Kvasnička (FITT STU Bratislava, Slovak Republic)

Jaroslav Novotný (FHS UK Praha, Czech Republic)

Jakub Novotný (VŠP Jihlava, Czech Republic)

Ján Pavlík (editor-in-chief) (VŠE Praha, Czech Republic)

Karel Pstružina (VŠE Praha, Czech Republic)

Miroslav Vacura (executive editor) (VŠE Praha, Czech Republic) 